e-ISSN: 2722-0966

Vol. 2 Issue 1

\title{
Study of ectoparasite prevalence and intensity on mud crab (Scylla serrata) in mangrove area of Wonorejo, Surabaya
}

\author{
Selobing Purna Agung Indarto*, Misbakhul Munir, and Dian Sari Maisaroh \\ Marine Science Department, Faculty of Science and Technology, UIN Sunan Ampel Surabaya, Indonesia \\ *E-mail: purnaobing@gmail.com
}

\begin{abstract}
This study aims to know various types, prevalence, and intensity of ectoparasite on mud crab (Scylla serrata) in mangrove area Wonorejo, Surabaya. This study used survey method with random sampling to collect the data. This study was conducted in July-December 2020. Ectoparasite in this study collected by smear method. In-situ water quality measurement were applied in this study. Mud crab in this study was obtained from local fisherman that consist of 30 crabs. There are 3 types of ectoparasite was infected mud crab there are Octolasmis sp. (208 ind), Zoothamnium sp. (93 ind), and Epistylis sp. (116 ind). Those ectoparasite was found in mud crabs gills. The highest prevalence was Octolasmis sp. (70\%), Epistylis sp. (30\%), and Zoothamnium sp. (23\%). The highest intensity was Zoothamnium sp (13.29 ind/crab), Epistylis sp. (12.89 ind/crab), and Octolasmis sp. (9.90 ind/crab). Based on Ministerial Decree of Ministry Environment and Forestry No. 1 of 2004 water quality in Wonorejo mangrove area was still optimal for life cycle of mud crab with average of temperature is $31.20^{\circ} \mathrm{C}$, Dissolved Oxygen $5.53 \mathrm{mg} / \mathrm{l}$, salinity $11 \mathrm{ppt}$, and pH 7.40.
\end{abstract}

Keywords: mud crab, ectoparasite, prevalence, intensity

\section{INTRODUCTION}

Mud crab (Scylla sp.) is a crab that spread in tropical and subtropical areas in the Indo-West Pacific region. There are four species of mud crab can be found in Indo-West Pacific, there are Scylla serrata, Scylla tranquebarica, Scylla olivacea and Scylla paramamosain. Scylla serrata is mostly found in the Indo Pacific region while Scylla tranquebarica can generally be found in the South China Sea region and lives in association with Scylla olivacea. Scylla paramamosain is very often found in continental regions of the South China Sea to the South Java Sea. The four mangrove crab species are associated with another species in the same geographic area [1].

To fulfill the supply of mangrove crab commodities in Indonesia generally rely on catches in nature. According to Indonesia Central Bureau of Statistics (BPS) [2] the composition of crab exports which rely on catches in nature is $65.3 \%$, while for cultivation products it has a lower value with percentage $34.7 \%$. Mangrove ecosystem is one of the main habitats for mud crab. Surabaya has several mangrove ecosystems that are still use as fisihng ground to catch mud crab by local fisherman. One of the mangrove ecosystems used to catch mud crab is Wonorejo mangrove area. The Wonorejo mangrove area has a good quality habitat for the growth of mud crab [3]. Food and Agricultural Security Service (DKPP) of Surabaya recorded total crab production in Surabaya in 2016 has reached 526.90 tons.

Disease on Scylla serrata were generally caused by the interaction of several factors with the host, including physiological conditions, host reproduction, environmental quality in water, growth rates, and pathogens. Pathogens that commonly infect mud crabs are bacteria, fungi, and parasites [4]. Water quality greatly affects the life cycle of mud crab. Change on water quality can cause the interaction between the host, environment and pathogen to be unbalanced. In unbalance situation the host will be easily infected by pathogen, common pathogens can be found on mud crabs is parasite [5].

Ectoparasite is very dangerous for mud crab because it can cause damage to body organs in mud crab, including body surface and disruptions on mud crab gills. This damage can cause secondary infection to the host like disruption of the growth of the host and causing the host's defense system to be decreased so the host can be easily attacked by bacteria and viruses and eventually cause death in the host [6,7]. Thus, this present study was conducted to investigate the occurrence of ectoparasites infection, prevalence, and intesity on mud crab (Scylla sp.) in mangrove areas of Wonorejo, Surabaya.

\section{RESEARCH METHODS Sample Collection}

This research was conducted in July-December 2020 at Wonorejo mangrove area, Surabaya. This study used a descriptive survey method with random sampling for collecting data. The parameter of this study was divided into two parameters, which are main parameters and secondary parameters. The main parameters are ectoparasite type, prevalence, and intensity. Secondary parameters are water quality which includes physical and chemical parameters such as temperature, $\mathrm{pH}, \mathrm{DO}$, and salinity. In-situ water quality measurement also measured. The water quality measurement stations were at 
coordinates 7³0'9.162 "S and 11283'4.693" T (Figure-1). Water quality measurement were measured in triplicate to get the average of measurement. The sampling areas are the fishing ground for the local fisherman to catch mud crabs.

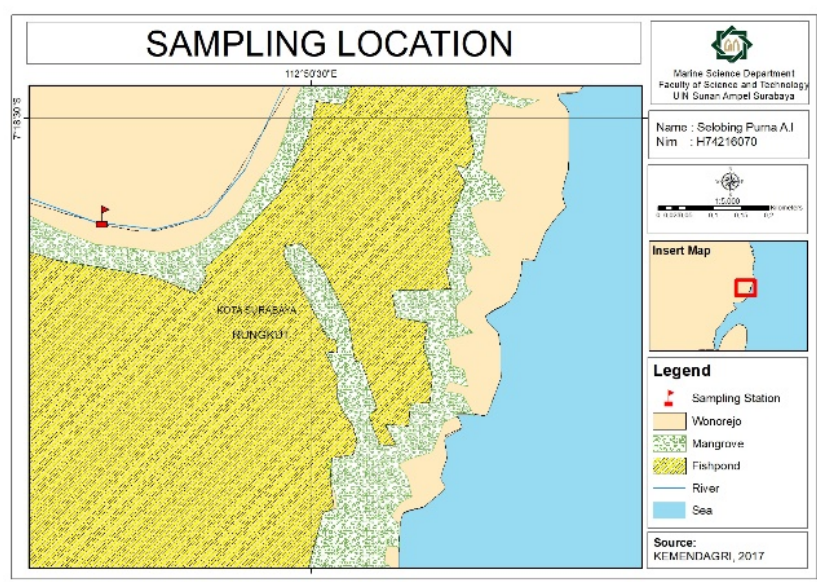

Figure-1. Wonorejo mangrove area

Mud crab samples were taken from $10 \%$ of total daily fishermen's catch [8]. Thirty wild mud crabs were collected from Wonorejo mangrove area. All crabs were examined in Basic Biology Laboratory, UIN Sunan Ampel and maintained in ice box which is filled with brackish water. The carapace width $(\mathrm{CW})$ and crabs body weight (BW) were measured using calipers and digital balance.

To examine ectoparasites from phylum Protozoa on Scylla serrata, smear method was apllied on the external parts of crabs; such as carapace, walking legs, swimming legs, and gills. The smeared organ then was placed on the object glass, dripped with distilled water, and observed under a microscope. To examine parasites on the gills, the carapace was opened using sectio set and the gills and crab's internal organs were separated into a petri dish. Furthermore, the gills also observed under a microscope with the same method [9]. The results of ectoparasites documentation from observations then were identified based on the identification key [10-13].

\section{Data Analysis}

The data that had been processed were analyzed descriptively. The data had been obtained in this study were divided into two types of data, namely the primary data i.e. prevalence and ectoparasite intensity data and supporting data i.e. water parameters data.

Prevalence is the percentage of parasitic infections that infected the entire host. The parasite prevalence $(P)$ was calculated from the total number of infected samples divided by the number of samples examined (Equation (1)) [1]. To find out the prevalence rate of infection was referred to criteria shown in Table-1 [14].

$$
P(\%)=\frac{\text { number of infected host }}{\text { total sample }} \times 100 \%
$$

Table-1. Prevalence rate classification

\begin{tabular}{|c|l|c|c|}
\hline No & \multicolumn{1}{|c|}{$\begin{array}{c}\text { Infection } \\
\text { Rate }\end{array}$} & Note & Prevalence \\
\hline 1 & Always & $\begin{array}{c}\text { Very severe } \\
\text { infection }\end{array}$ & $100-99 \%$ \\
\hline 2 & $\begin{array}{c}\text { Almost } \\
\text { always }\end{array}$ & $\begin{array}{c}\text { Severe } \\
\text { infection }\end{array}$ & $98-90 \%$ \\
\hline 3 & Usualy & $\begin{array}{c}\text { Moderate } \\
\text { infection }\end{array}$ & $89-70 \%$ \\
\hline 4 & Very often & $\begin{array}{c}\text { Very often } \\
\text { infection }\end{array}$ & $69-50 \%$ \\
\hline 5 & Generaly & $\begin{array}{c}\text { Common } \\
\text { infection }\end{array}$ & $49-30 \%$ \\
\hline 6 & Frequent & $\begin{array}{c}\text { Often } \\
\text { infection }\end{array}$ & $29-10 \%$ \\
\hline 7 & Sometimes & $\begin{array}{c}\text { Sometimes } \\
\text { infection }\end{array}$ & $9-1 \%$ \\
\hline 8 & Rarely & Rare infection & $>1-0,1 \%$ \\
\hline 9 & Very rare & $\begin{array}{c}\text { Very rare } \\
\text { infection }\end{array}$ & $>0,1-0,01 \%$ \\
\hline 10 & Never & Never & $>P 0,1 \%$ \\
\hline
\end{tabular}

Intensity of ectoparasite were defined as the mean number of parasites in all infected hosts. The value of parasite intensity $(I)$ was calculated from number of parasites divided by number of infected crabs (Equation (2)) [8]. To find out the intesity criteria of ectoparasite were refers to criteria shown in Table-2 [15].

$I=\frac{\text { number of parasite }}{\text { number of infected crab }}$

Table-2. Criteria of intensity

\begin{tabular}{|c|l|}
\hline Intensity & \multicolumn{1}{|c|}{ Criteria } \\
\hline$<1$ & Very low \\
\hline $1-5$ & Low \\
\hline $6-50$ & Medium \\
\hline $51-100$ & Severe \\
\hline$>100$ & Awfully \\
\hline$>1000$ & Super Infection \\
\hline
\end{tabular}

\section{RESULTS AND DISCUSSIONS Clinical Signs}

Obsevation of clinical sign were started from outside the crab's body and gills. Observation shown that there was a small object's sprouts-shaped attached on crab gills and there were discolouration of the gills, the gills becomes blackish-brown (Figure-2). Those clinical signs are generally seen on infected mud crab's [16]. There were some crab's samples that showed no clinical signs but infected by ectoparasites.

Clinical sign of Octolasmis sp. can be seen immediately when looking at the gills. Octolasmis sp. shaped like white and orange sprouts attached to gills of Scylla serrata. Protozoan parasite did not show any clinical sign in mud crabs. 


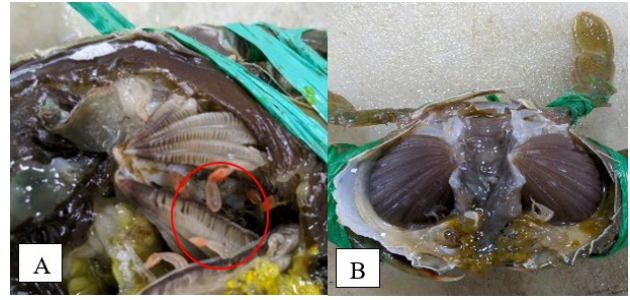

Figure 2. Clinical sign on mud crab, individu like sprout shaped (A) and discolouration of gills (B).

\section{Types of Ectoparasite}

There were two phylums of mud crab's ectoparasites infection in Wonorejo mangrove area, they are Octolasmis sp. (Arthropoda), Zoothamnium sp. (Protozoa), and Epistylis sp. (Protozoa). The number of ectoparasite were found in gills of mud crabs is shown in Figure-3.

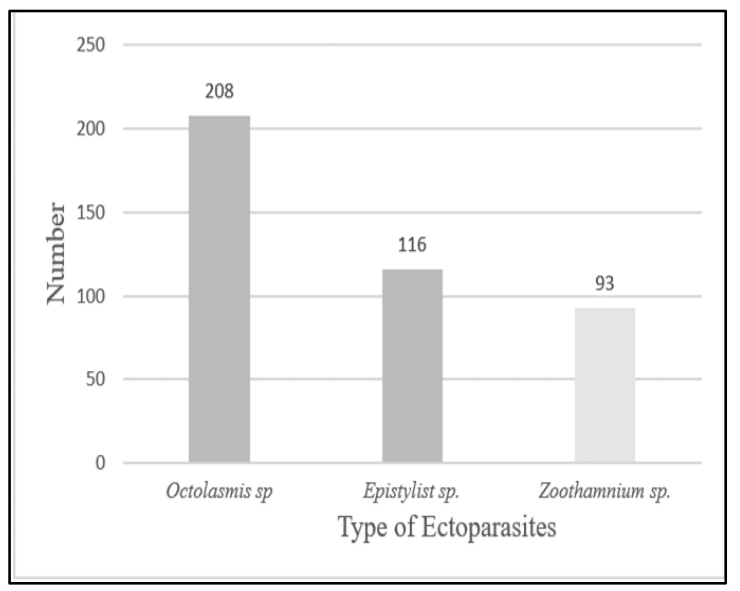

Figure-3. Number of ectoparasite was found on mud crabs

\section{- Octolasmis sp.}

Octolasmis sp. is an ectoparasite which has a sproutlike shape usually found attached on the gill's crabs. Morphological observations of Octolasmis sp. shown it has peduncel, carina, scutum, legs, and tergum. In this study has found two species of Octolasmis sp., they are Octolasmis cor and Octolamsis angulata. [13] described Octolasmis angulata have a thin scutum and and L-shape and its carina is narrow, while Octolasmis cor has a carina which has a shape like the letter $\mathrm{T}$ and wide. Morphological observation of Octolasmis sp. shown in Figure-4.

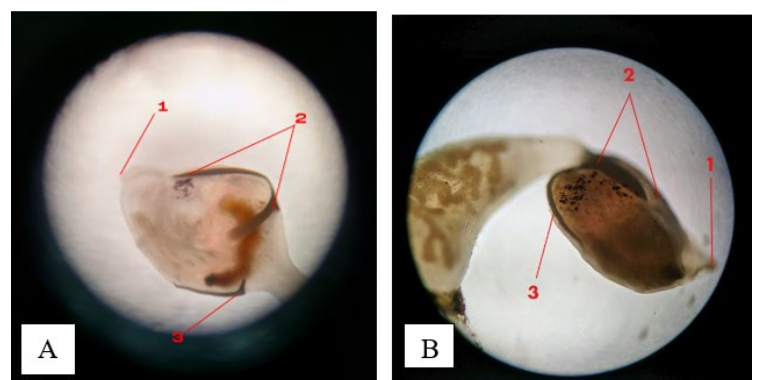

Figure-4. Octolasmis angulata (A) and Octolasmis cor (B) with tergum (1), carina (2), scutum (3).

Octolasmis sp. has a body size of 0.01-0.15 cm with the morphology that colonizes the gills, has a capitulum, bergum, carina, scutum, and legs. Carina serves as a protector of the internal organs. Capitulum on Octolasmis sp. functionate as a stomach that can destroy food so that nutrients can be digested properly. Tergum functionate as the mouth, the scutum functionate as the intestine which is used to absorb food juices, and the feet are used to attach to the host [8].

\section{- $\quad$ Epistylis sp.}

The characteristics of Epistylis sp. is branching on the stalk, zooid shaped like an inverted bell, and colonize. This parasite is not contractile on the stem because it does not have myoneme. Morphological observations shown that Epistylis sp. has a zooid, stalk, macronucleus, peristomial lips, and peristomial disk. Observations of Epistylis sp. shown in Figure-5. Based on [17] Epistylis sp. caused hemmorhagic uclear disesae on the host. Epistylis sp. associtaed with microfloral bacteria. The changes of phatological caused by bacterial protelyotic enzymes.

The protozoan ectoparasites, such as Zoothamnium sp., Epistylis sp., Vorticella sp., and Acineta sp. were usually found in crab gills. These parasites can lead problems in the hatching phase, especially the egg and larval stage in aquaculture activities. Those problems are generally closely related to water quality. Epistylis sp. is easily found in water with low dissolved oxygen, according to previous research [18].

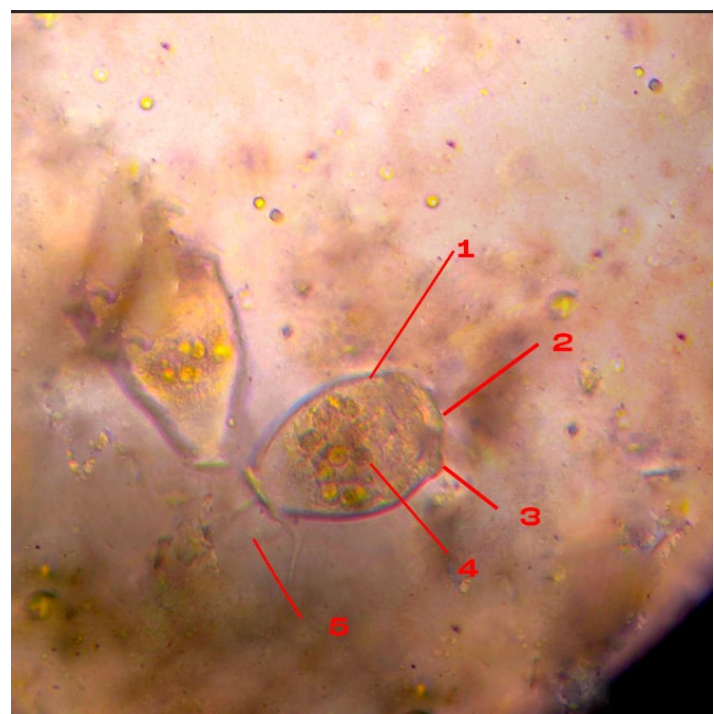

Figure-5. Epistylis sp. with zooid (1), peristomial disk (2), peristomial lips (3), nucleus (4), and stalk (5) (record at 40x magnification)

- Zoothamnium sp.

Zoothamnium sp. shaped like inverted bell-shaped zooid, contractile stalk, zooid capable to contracting, colonizing, and having many branches on each stalk. Morphological observations shown that Zoothamnium sp. have cilia, zooid, myoneme, stalk, and nucleus. Observations of Zoothamnium sp. shown in Figure-6. Zoothamnium sp. colony attach on the the host using a pedicel or stalk. When Zoothamnium sp. has attached to the host, Zoothamnium sp. will injected a specific substance or can be called a specific mucus which can cause damage to the host organ especially gills [19].

Zoothamnium sp. infected crab and shrimp larvae. Zoothamnium sp. infected mud crab at zoea 5 stage and megalopa phase. Infection of Zoothamnium sp. in the 
larval phase it can lead the larvae to mass death in crab cultivation. This parasite can lead to abnormal shape of crab larvae, leading to the increase of mortality [20].

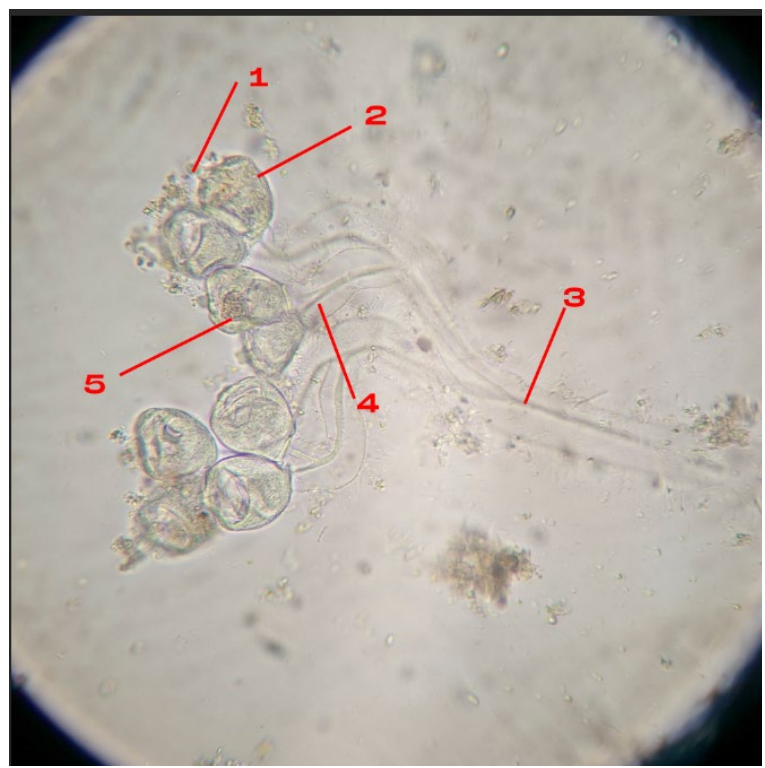

Figure-6. Zoothamnium sp. with silia (1), zooid (2), myoneme (3), stalk (4), and nucleus (5) (record at 40x magnification)

\section{Prevalence and Intensity}

Prevalence is the percentage ratio between the number of samples infected with ectoparasites and the total number of samples was examined. Based on Table-3, the highest prevalence of ectoparasites is Octolasmis sp. with prevalence value $70 \%$ followed by Epistylis sp. with a prevalence value of $30 \%$ and the lowest prevalence value is Zoothamnium sp. with a value of prevalence $23 \%$. Based on the category of parasite prevalence values [14] the prevalence of Octolasmis sp. is moderate prevalence level where the prevalence rate of Octolasmis sp. can cause stress to the host but not lead death of the host. Prevalence of Epistylis sp. is the usual prevalence level where this infection is common in mud crab. The prevalence of Zoothamnium sp. categorized into frequent prevalence, this illustrated that Zoothamnium sp. often found infected mud crab in the Wonorejo mangrove area.

Intensity is the ratio between the number of individual parasites and the total number of infected crabs. The result of the intensity calculation shows that the highest parasite intensity value is Zoothamnium sp. with intensity $13.29 \mathrm{ind} / \mathrm{crab}$, Epistylis sp. with intensity value 12.89, and Octolasmis sp. with intensity value 9.90 ind/crab. Based on intensity category by [15] had shown that all parasite intensity in mud crab is at moderate intensity. Moderate intensity can indicate those parasites can causes stress on the host but does not lead death of the host [8]. The calculation of the prevalence value and ectoparasite intensity were also calculated based on weight of the crab (BW) and width of the carapace $(\mathrm{CW})$. The results of calculation based on the weight of the crab can be seen in Table- 4 and the calculation results based on the width of the carapace can be seen in Table- 5 .

The prevalence and intensity values based on the weight of the crabs, there are increasing value in the intensity and prevalence values in the 78-85 gram - 103110 gram. The highest prevalence and intensity values based on the width of the carapace are in the $65-68 \mathrm{~mm}$, $69-72 \mathrm{~mm}$, and $85-88 \mathrm{~mm}$ where the prevalence value reaches $100 \%$, because in those classes were found ectoparasites infected on those class. In the 73-76 $\mathrm{mm}$ to $81-84 \mathrm{~mm}$ there is an increasing value in the prevalence value and the number of ectoparasites. The increasing age of the host, the morphological and physiological changes will affect the surface area of the host body to become wider. Host size will also affect the fluctuation of ectoparasite intensity on the host [21].

Wider surface area of ectoparasite would increase it intensity value [22]. Also, there was positive correlation between the width of carapace and percentage of parasite intensity in Callinectes ornatus [23]. Prevalence and intensity of parasites has different values on the host in the juvenile phase and the adult host, also on the male and female hosts. Longer exposure of parasites to the host will lead to the increase of its intensity and prevalence value [21].

Table-3. Prevalence and intensity of ectoparasite

\begin{tabular}{|c|c|c|c|c|c|}
\hline Ectoparasite & Number of Parasite & Examined Crab & Infected Crabs & Prevalence & Intensity \\
\hline Octolasmis $s p$ & 208 & 30 & 21 & $70 \%$ & 9.90 \\
\hline Epistylis $s p$. & 116 & 30 & 9 & $30 \%$ & 12.89 \\
\hline Zoothamnium $s p$. & 93 & 30 & 7 & $23 \%$ & 13.29 \\
\hline
\end{tabular}

Table-4. Prevalence and intensity of ectoparasite based on body weight

\begin{tabular}{|c|c|c|c|c|c|}
\hline BW (gr) & Examined Crab & Infected Host & Number of Parasite & Prevalence & Intensity \\
\hline $70-77$ & 2 & 2 & 39 & $100 \%$ & 19.5 \\
\hline $78-85$ & 7 & 4 & 65 & $57 \%$ & 16.25 \\
\hline $86-93$ & 9 & 7 & 95 & $78 \%$ & 13.57 \\
\hline $94-102$ & 5 & 4 & 93 & $80 \%$ & 23.25 \\
\hline $103-110$ & 6 & 4 & 122 & $67 \%$ & 30.5 \\
\hline $111-118$ & 1 & 1 & 3 & $100 \%$ & 3 \\
\hline
\end{tabular}


Table-5. Prevalence and intensity of ectoparasite based on carapace width

\begin{tabular}{|c|c|c|c|c|c|}
\hline CW (mm) & Examined Crab & Infected Host & Number of Parasite & Prevalence & Intensity \\
\hline $65-68$ & 1 & 1 & 23 & $100 \%$ & 23.00 \\
\hline $69-72$ & 2 & 2 & 51 & $100 \%$ & 25.50 \\
\hline $73-76$ & 13 & 7 & 99 & $54 \%$ & 14.14 \\
\hline $77-80$ & 5 & 4 & 106 & $80 \%$ & 26.50 \\
\hline $81-84$ & 7 & 6 & 110 & $86 \%$ & 18.33 \\
\hline $85-88$ & 2 & 2 & 28 & $100 \%$ & 14.00 \\
\hline
\end{tabular}

\section{Water Quality}

The results of water quality measurements indicate that these environement are still optimal for mangrove crab life based on the quality standards that have been set in Ministerial Decree Ministry of Environment and Forestry No. 51 of 2004 . The results of water quality condition are shown in Table-6. If water quality decreased from its natural conditions can cause mud crab immunity, so it can be easily attacked by pathogens. One of the pathogens that can cause disease is parasites [20]. The optimal water salinity for parasite development is $30-35 \%$, $\mathrm{pH}$ is in the range of $7.63-8.80$, temperature $28-31^{\circ} \mathrm{C}$ [8].

Table-6. Water condition

\begin{tabular}{|l|c|c|}
\hline \multicolumn{1}{|c|}{ Parameter } & Average & $\begin{array}{c}\text { Ministerial Decree } \\
\text { Ministry of } \\
\text { Environment and } \\
\text { Forestry No 51/2004 }\end{array}$ \\
\hline $\mathrm{DO}(\mathrm{mg} / \mathrm{l})$ & 5.53 & $>5 \mathrm{mg} / 1$ \\
\hline $\mathrm{pH}$ & 7.40 & $7-8.5$ \\
\hline Temperature $\left({ }^{\circ} \mathrm{C}\right)$ & 31.20 & $28-32^{\circ} \mathrm{C}$ \\
\hline Salinity $(\mathrm{ppt})$ & 11.00 & $\mathrm{~s} / \mathrm{d} 34 \mathrm{ppt}$ \\
\hline
\end{tabular}

Distribution of Octolasmis sp. highly influenced by changes in seasons, high rainfall might indirect the water salinity, lower salinity could affect intensity and prevalence of Octolasmis sp. Mud crabs in environment with high salinity will have a high chance for Octolasmis sp. stick to the host. The high rainfall could affect the water salinity value, it will lead changes in eating habits, reproduction, metabolism, and the life cycle process of Octolasmis sp [24]. The results of research by [4] found that Octolasmis sp. as many as 201 individuals in waters with a temperature range of $28.1-31.4{ }^{\circ} \mathrm{C}$, DO $4.7-7.7 \mathrm{mg}$ /1, salinity 7-28 ppt, and $\mathrm{pH}$ 7.23-7.60.

\section{REFERENCES}

[1] Ihwan, M. Z., Wahidah, W., Ambak, M. A., Ikhwanuddin, M., and Marina, H. 2015. Investigation of Parasite and Ecto-Symbiont in Wild Mud-Crab Genus Scylla from Trengganu Coastal Water Malaysia: Prevelance and Mean Intensity. International Journal of Zoological Research. 11(4): 151-159. https://dx.doi.org/10.3923/ijzr.2015.151.159

[2] Badan Pusat Statistik (BPS). 2018. Data EksporImpor 2012-2017. Jakarta.

[3] Hanjani, A. 2019. Analisis Ekologi dan Morfometrik Kepiting Bakau (Scylla serrata) pada Kawasan Estuaria di Pesisir Wonorejo, Rungkut, Surabaya. Skripsi. UIN Sunan Ampel. Surabaya.
High dissolved oxygen will affect the intensity and prevalence of Epistylis sp. in mud crab. Epistylis sp. is a parasite that can develop optimally in waters with low dissolved oxygen and have a substrate [20]. Epistylis sp. can develop optimally in waters with temperature 10$25{ }^{\circ} \mathrm{C}$, salinity of $15-31 \mathrm{ppt}$, and $\mathrm{pH}$ 6.5-7.0 [16]. In another research Epistylis sp. were found in mud crab with water temperature $30-31^{\circ} \mathrm{C}, \mathrm{pH} 8$, and the salinity is in the range of 31-35 ppt [8].

Zoothamnium sp. is one of the parasites whose life is not influenced by water quality. Zoothamnium sp. can live in waters with good or bad quality. Colony of Zoothamnium sp. will be found in waters with temperature range $22.25-24.11^{\circ} \mathrm{C}$ and salinity 34.9 ppt [25]. Zoothamnium sp. also found in waters with temperature 28.1-31.4 ${ }^{\circ} \mathrm{C}$, DO 4.7-7.7 mg/l, salinity 7-28 ppt, and $\mathrm{pH}$ 7.23-7.60 [4].

\section{CONCLUSIONS}

There are three types of ectoparasites from phylum protozoa and arthropoda which infected mud crab (Scylla serrata) in Wonorejo mangrove area, those ectoparasites are: Octolasmis sp., Zothamnium sp., and Epistylis sp. All parasites were only infected on the gills of mud crabs. The highest parasite prevalence is Octolasmis sp. (70\%) categorized as moderate prevalence, Epistylis sp. (30\%) categorized as the usual prevalence, Zoothamnium sp. (23\%) categorized as frequent prevalence. The highest parasite intensity is Zoothamnium sp. (13.29 ind/crab), Epistylis sp. (12.89 ind/crab), and Octolasmis sp. (9.90 ind/crab) all ectoparasite intensities were categorized into the moderate category. Based on our study, the increase of crab's size would affect to ectoparasites prevalencies and intensity.

[4] Muttaqin, I., Julyantoro, P. G., and Sari, A. H. 2018. Identification and Predilection of Mangrove Crab Ectoparasites (Scylla spp.) From the Forest Park Mangrove Ecosystem (TAHURA) Ngurah Rai, Bali. Current Trends in Aquatic Science. 1(1): 24-31.

https://doi.org/10.24843/CTAS.2018.v01.i01.p04

[5] Lerssutthichawal, T. and Penrapai, N. 2013. Seasonal Distribution and Host-Parasite Interaction of Pedunculate Barnacle, Octolasmis spp. on Orange Mud Crab, Scylla olivacea. Walailak Journal. 10(2): 113-119.

http://dx.doi.org/10.2004/wjst.v10i2.508 
[6] Muchlisin, Z. A., A. M. Munazir, Z. Fuady, W. Winaruddin, S. Sugianto, M. Adlim, N. Fadli and A. Hendri. 2014. Prevalence of ectoparasites on mahseer fish (Tor tambra Valenciennes, 1842) from aquaculture ponds and wild population of Nagan Raya District, Indonesia. HVM Bioflux. 6(3):148152

[7] Novita, D., T. R. Ferasyi dan Z. A. Muchlisin. 2016. Intensitas dan prevalensi ektoparasit pada udang pisang (Penaeus sp.) dari tambak budidaya di pantai barat Aceh. Jurnal Ilmiah Mahasiswa Kelautan Perikanan Unsyiah. 1(3): 268-279.

[8] Irvansyah, M. Y., Abdulgani, N., Mahasri, G. 2012. Identifikasi dan Intensitas Ektoparasit Pada Kepiting Bakau (Scylla serrata) Stadia Kepiting Muda di Pertambakan Kepiting Kecamatan Sedati Kabupaten Sidoarjo. Jurnal Sains dan Seni ITS. 1(1):

5-11. http://dx.doi.org/10.12962/j23373520.v1i1.1105

[9] Handayani, L., Rozikin, I. 2019. Identifikasi Ektoparasit pada Kepiting Bakau (Sylla serrata) dari Hasil Tangkapan Nelayan di Wilayah Pertambakan Desa Segintung Kuala Pembuang II. Sebatik. 23(1): 72-76.

[10] Bick, H. 1972. Ciliated Protozoa. World Health Organization. Genva.

[11] Bierhof, M. J. and Roos, P.J. 1977. Sedentary Ciliates from Two Dutch Fresh Water Gammarus Species. Bijdragen Tot De Dierkunde. 46(2): 151170.

[12] Jeffries, W. B., Voris, H. K., Naiyanetr, P., \& Panha, S. 2005. Pedunculate Barnacles of the Symbiotic Genus Octolasmis (Cirripedia: Thoracica: Poecilasmatidae) from the Northern Gulf of Thailand. Tropical Natural History. 5(1): 9-13. Retrieved from https://i01.tcithaijo.org/index.php/tnh/article/view/102887

[13] Chan, B.K.K., Prabowo, R.E., Lee, K.S. 2009. Crustacean Fauna of Taiwan Barnacles Volume ICirripedia: Thoracica Excluding The Pyrgomatidae and Castinae. National Taiwan Ocean University. Taiwan.

[14] William, E.H. and Bunkley, W.L. 1996. Parasites of Offshore Big Game Fishes of Puerto Rico and The Western Atlantic. University of Puerto Rico. Puerto Rico.

[15] Yusni, E. and Haq, F.A. 2020. Inventory and prevalence of ectoparasites Octolasmis sp. in the mangrove crab (Scylla tranquebarica) in Lubuk Kertang, Langkat. IOP Conference Series: Earth and Environmental Science 454. pp. 1-6. doi:10.1088/1755-1315/454/1/012121

[16] Fitriyani, S., Desrina, Haditomo, A.H.C. 2016. Ektoparasit Kepiting Bakau (Syclla serrata) dari Perairan Desa Wonosari Kabupaten Kendal. Prosiding Seminar Nasional Hasil Penelitian Perikanan dan Kelautan VI. pp. 554-565.

[17] Padua, S., Martin, M., Vallado, G., Utz, L., Zara, F., Ishikawa, M., and Belo, M. 2016. Host-parasite relationship during Epistylis sp. (Ciliophora: Epistylididae) infestation in farmed cichlid and pimelodid fish. Pesq. Agropec. Bras. 51(05): 520526. https://doi.org/10.1590/S0100-
[18] Jithendran, K., P., Poornima, M., Balasubramanian, Kulasekarapandian, S. 2010. Diseases of Mud Crabs (Syclla, spp.): An Overview. Indian J. Fish. 57(3): 55-63.

[19] Mahasri, G., Raya, L., Mubarak, S., Irawan, B. 2008. Gambaran Patologi Insang dan Kulit Udang Windu (Penaeus Monodon Fab.) yang Terserang Ciliata Patogen dari Famili Vorticellidae (Zoothamnium sp.). Berkala Ilmiah Perikanan. 3(1): 95-103.

[20] Linh, N.K., Khoa, T.N., Zainathan, S.C., Musa, Nadhirah, Musa, Najiah, Harrison, F. 2017. Development of Mud Crab Crablet, The Identification of Ciliates and The Bioefficacy of Leaf Extract of Rhizophora apiculata as AntiProtozoal Agent. Journal of Sustainability Science and Management. 12(2): 52-65.

[21] Alifudin, M., Hadiroseyani, I., Ohoiulun, I. 2003. Parasit pada Ikan Hias Air Tawar (Ikan Cupang, Gapi dan Rainbow). Jurnal Akuakultur Indonesia. 2(2): 93-100. https://doi.org/10.19027/jai.2.93-100

[22] Bawia, R.H., Tuiyo, R., Mulis. 2015. Prevalensi dan Intensitas Ektoparasit Monogenea Cichlidogyrus sp pada Insang Ikan Nila dengan Ukuran yang Berbeda di Keramba Jaring Apung Danau Limboto. Jurnal Ilmiah Perikanan dan Kelautan. 2(2): 6065. https://doi.org/10.37905/.v2i2.1254

[23] Santos, C. and Bueno, S. 2002. Infestation by Octolasmis Lowei (Cirripedia: Poecilasmatidae) In Callinectes Danae and Callinectes Ornatus (Decapoda: Portunidae) from São Sebastião, Brazil. Journal of Crustacean Biology. 22(2): 241-248. https://doi.org/10.1163/20021975-99990231

[24] Khotimah, A., Rokhmani, Riwidiharso, E. 2018. Prevalensi dan Kelimpahan Vorticella sp. pada Kepiting Bakau (Scylla serrata) yang Didaratkan di Tempat Pelelangan Ikan Sleko Kabupaten Cilacap Jawa Tengah. Prosiding Seminar Nasional Masyarakat Biodiversitas Indonesia. pp. 87-91.

[25] Munir, S., Sun, J., 2018. The first snapshot study on horizontal distribution and identification of five peritrich ciliates (Genus Vorticella Linnaeus and Zoothamnium Bory de St. Vincent) from the eastern Indian Ocean. Acta Oceanol. Sin. 37: 79-85. https://doi.org/10.1007/s13131-018-1303-4 